\title{
Shared Development: Theoretical Thoughts of Chinese People's Livelihood Issues
}

\author{
Jinsong Zhang \\ College of Marxism, Jilin Agricultural University, Changchun 130000, China
}

\begin{abstract}
Keywords: Sharing Development, People's Livelihood, Free and Overall Development.
\end{abstract}
\begin{abstract}
The five development concepts are the new development concepts that are put forward by the party and the government in the face of the new normal of economy development and the change of global pattern, whose shared development is ideological concept that plays collectively leading role in the people's livelihood and economic development. It can more accurately lead the development direction and focus of our people's livelihood by understanding theoretical connotation of shared development concept deeply, knowing its objectives and the essence, and achieve the efficient, fair and sustainable people's livelihood development. At the same time, the shared developments are also the macroscopic planning of China's economic structural reform and new specification for the economic development order
\end{abstract}

\section{Introduction}

Since the quantification of China's economic and social development goals and strategies, the people's livelihood development has become an important dimension to verify the socialist road with Chinese characteristics, the top-level designs of national policy are more targeted to face the people life, created more than 30 years flourishing age. While amazing at the miracle of China, people began to actively explore theory on the people's livelihood issues and tried to find out more powerful ideological basis and material strength behind the China's development. [1]

\section{Shared development}

Shared development is a strategic thinking of the people's livelihood proposed by Communist Party in comprehensively grasping contradictions between people's demand and the social supply, which is practical strategy for our country to realize a well-off society in an all-round way. Engels said: " Where does history start, where thought process begins, and the further development of the thought process is a reflection where historical process in the abstract, theoretical and consistent form". [2] Shared development concept adapt to the further development of China's reform and rise in response to the proper time and conditions, which from the reality of the people's needs, and it is representational interpretation to enjoy a happy life together.

Shared development is a national thinking that relationship of harmonize social relation and maximally promotes the development of productive forces. Marx once said: "No matter how individual subjectively detach all kinds of relationship, he is always the product of these relationships in the social sense." [3] "The meaning of social relations is the common activities of many individuals ... and these common activities themselves are the 'productive force'. [4] The foundation of harmonious society is to achieve social equality in the development road of China characteristic socialism, the establishment of the leadership of the Communist Party of China, the people's democratic dictatorship, socialist democracy and the rule of law, the socialist core value system and the socialist market economic system and other new social development system, which build the most equal social relations so far in human history. This equality not only eliminates the gap between people due to differences of economic and political status, but also brings more than expected reciprocal growth to social development. China's economic growth rate have increased $7 \%$ per year over the past 30 years, which has not only solved the problem of food and clothing for 700 million 
people, but also has become the world's most powerful new economy, it fully embodies the great impetus of China's new social relations. Meanwhile, shared development concept maximizes the development of productive forces, which also clears the party and the government's responsibility for citizens and society. President Xi emphasized: "The eradication of poverty, the improvement of people's livelihood and the realization of common prosperity are essential requirements of socialism, important mission of our party." [5] The establishment of socialist democratic politics and the socialist market economy fully ensured the citizen's democratic rights, reasonable allocation of resources are achieved, maximize the liberation and development of the productive forces, "when people has finally recognized the nature and treat this productive forces in accordance with today's productivity, the anarchy of social production will give way to the social planned adjustment for the production in accordance with the overall and each member's needs. " [6]

Shared development is macroscopic planning setting to comprehensively deepen reform of China, which is re-regulation of the economic development order and a strategy for China to solve "two problems". [7] After 30 years of rapid growth, with the increase in economic volume, China's economic development has entered into a slow period, which is the inevitable law of economic development. But once the thinking consciousness of only economic theory, the increasing gap between the rich and the poor and middle-income trap risk is still accumulating. Shared development solve these development problems by purposeful macroscopic planning, the ultimate goal of the people's livelihood and happiness push the form and content of China's economic and social development, innovation, coordination, green, open, sharing five development concept are proposed, this five development concept standardize the economic order in our country, meanwhile pointed out the prospect and direction of the China's social development, development vitality and potential are enhanced by the government adjusting economic structure, the economic sustainable development are promoted through the combination of long-term planning and short-term development, ensure the stable operation of the economic order. For example, Prime Minister Li Keqiang said: "the Chinese economy likes riding a bicycle, the distance should be seen, the present problem also should be seen clearly, it is to see far and regulate near." [8]

Shared development is the innovation and development of the socialist distribution system with public ownership as the main body. A kind of thing based on their inner contradictions and the reflection of eternal change process, which will have certain regularity, inevitability, rationality. After several decades of socialist construction, China has established distribution system of socialist primary stage with distribution according to work and multiple distributions, which solves the poverty and development problem of the vast majority of the population. But the systematic immaturity cause efficiency and fair problem to be difficult to solve, polarization between the rich and the poor and the inequitable distribution phenomenon still exist. With the continuous development and improvement of socialist politics, economy, society and culture, the improvement of productivity level, the great accumulation of material wealth, the change of people's production and life style, the thinking and idea of resolving the contradiction between efficiency and fairness are mature, the shared development concept is the innovation and development of distribution pattern in the middle and later periods of primary stage of socialism in China, it is in line with the law of social development. As Marx said: "the distribution in terms of its decisive characteristic, it is always inevitable result of production and exchange relations and the historical premise of this society, and as long as we know these relations and premises, we can authentically infer the dominant distribution mode in this society ". [9].

\section{Conclusion}

The concept of shared development is that actual productivity guides production relations, which is automatic theoretic distillation of social relations of socialism with Chinese characteristics. The modern social relations based on concept of shared development will be a strong driving force for socialism with Chinese characteristics; its external performances are the practice and materialization 
of Chinese thought and idea. To comprehensively build a well-off society and reach the standard of moderately developed countries are China's thinking, One Belt And One Road construction, the Asian Infrastructure Investment Bank is also materialization of Chinese thought. Al Karam Casas said: "compared to China before the 1980s, China now has made great progress and has undergone tremendous changes, it learn economic development lessons from from the west, and combined with the practice but not blindly copy... China succeeds in maintaining independence, does not apply mechanically from other countries' successful experience, combine theory with practice, and avoid the country into the end of the western subsidiary".

Under the guidance of shared development concept, profound changes happen in China's socialist production relations, social relations inevitably, their own unique advantages promote sustainable development of the society, and the practice proved that socialism with Chinese characteristics has been on the road, the future of communism will be inevitable.

\section{References}

[1] Marx has pointed out in " Critique of Hegel's Philosophy of Right": "critical weapons cannot certainly replace the criticism of weapons, material forces can only be destroyed by material power, but the theory once are mastered by the masses, it will change the material strength, as long as theory persuade people, it can grasp the masses; and as long as theory is complete, people can be persuaded. The so-called complete, it is to seize the foundation of things, but people simply are the person itself, ("Anthologies of Marx \& Engels", Vol.1, pp.9).

[2] "Anthologies of Marx \& Engels", People's Publishing House, 2009, Vol. 2, pp.603.

[3] "Anthologies of Marx \& Engels", [M], People's Publishing House, 1995. Vol.2, pp.102.

[4] "Anthologies of Marx \& Engels", [M], People's Publishing House, 1995. Vol.1, pp.80

[5] Xi Jinping, "ensure the rural population overcomes poverty by 2020 on schedule", Xinhuanet: http: //news.xinhuanet.com/2015-06-19/e1115674737.htm

[6] Engels "Socialism from the utopian to the scientific development", People's Publishing House, 1997, p.72.

[7] The two major problems are that the polarization between the rich and the poor intensifies and traps into the middle-income countries.

[8] Prime Minister compares riding a bike to China's economic, emphasis on base, April 15, 2015, First Financial Daily,

[9] http: //finance.sina.com.cn/china/20150415/012621956672.shtml

[10] "Anthologies of Marx \& Engels" Vol. 3, People's publishing House, 1995, p.496.

[11] http://www.youm7.com/story/2014/12/22/\%d9\%88\%d9\%84\%d9\%88-\%d9\%81\%d9\%89-\%d8 \%a7\%d9\%84\%d8\%b5\%d9\%8a\%d9\%86/1998682\#.VWqmS-n9m74 